\title{
Jaringan Jemaat dan Lokasi sebagai Basis Eksistensi Tempat Pembinaan Iman (Gereja) di Mall Kota Bekasi
}

\author{
Yusnita Oktaviani \\ Departemen Arsitektur dan Perencanaan, Fakultas Teknik \\ Universitas Gadjah Mada (UGM) \\ e-mail: yusnitaoktaviani02@gmail.com
}

\begin{abstract}
Abstrak - Pertumbuhan eksistensi tempat pembinaan iman di mall sering dijumpai di beberapa kota besar di Indonesia dan salah satunya di kota Bekasi. Perkumpulan jemaat Kristen yang berlokasi di mall disebut sebagai tempat pembinaan iman. Tempat pembinaan iman yang diadakan oleh organisasi Kristen di mall merupakan ide baru dari aliran Kharismatik dalam pemilihan preferensi lokasi. Tujuan penelitian adalah untuk mengeksplor dan memahami terjadinya fenomena jaringan jemaat dan lokasi sebagai basis eksistensi gereja di mall Kota Bekasi. Metode yang digunakan pada penelitian ini adalah induktif - kualitatif dengan pendekatan fenomenologi. Penelitian tidak hanya mengeksplor secara fisik (ruang) saja namun juga melihat dari sisi nilai ruang, aktivitas pada ruang, dan aktor yang terlibat dalam eksistensinya. Lokasi penelitian berada di Jalan Ahmad Yani yang merupakan zona ruang campuran dimana mall saat ini tidak hanya sebagai ruang komersial tetapi juga menjadi ruang peribadatan. Ditambah lagi, di sepanjang Jalan Ahmad Yani terdapat tiga mall yang menjadi titik berkumpulnya jaringan komunitas yang merupakan jemaat Kristen. Selain itu, mall juga sebagai jaringan lokasi tempat pembinaan dengan adanya tiga mall yang memiliki tempat pembinaan iman dari komunitas Kristen yang beda. Oleh karena itu, dari proses induksi sejak awal tahun 2000-an sampai sekarang tidak dapat terlepas dari jaringan lokasi dan jaringan jemaatnya.
\end{abstract}

Kata Kunci — Eksistensi, Tempat Pembinaan Iman, Mall, Jaringan Lokasi, Jaringan Jemaat

\section{PENDAHULUAN}

$\mathrm{K}$ ota Bekasi merupakan kota penyangga Ibu Kota Jakarta, dimana kota ini menjadi tempat tinggal bagi para penduduk yang bekerja di Jakarta. Di tahun 2020, jumlah penduduk sudah mencapai 2,45 juta jiwa. Selain itu, Menurut data Disdukcapil pada tahun 2017, pendatang di kota Bekasi mencapai 100 ribu orang per tahun. Penduduk di kota Bekasi menduduki peringkat ketiga tertinggi setelah DKI Jakarta dan Surabaya. Hal ini menyebabkan heterogenitas penduduk dengan berbagai macam suku, ras, dan agama. Keberagaman agama pada penduduk kota Bekasi juga menyebabkan keberagaman tempat ibadah seperti masjid, gereja Kristen, gereja Katholik, pura, dan vihara. Gereja Kristen merupakan rumah ibadah terbanyak ke dua setelah masjid, berbanding lurus dengan jumlah penduduk beragama Kristen Protestan yang jumlahnya menempati peringkat kedua setelah umat Islam di Kota Bekasi. Seiring dengan berjalannya waktu, rumah ibadah umat Kristen tidak lagi ditemui hanya sebagai rumah ibadah yang berdiri sendiri secara permanen, namun ada pula yang berlokasi di ruko, mall, hotel, dan gedung serbaguna.
Keberagaman pemilihan berdasarkan preferensi yang dipilih oleh masing-masing pengelola.

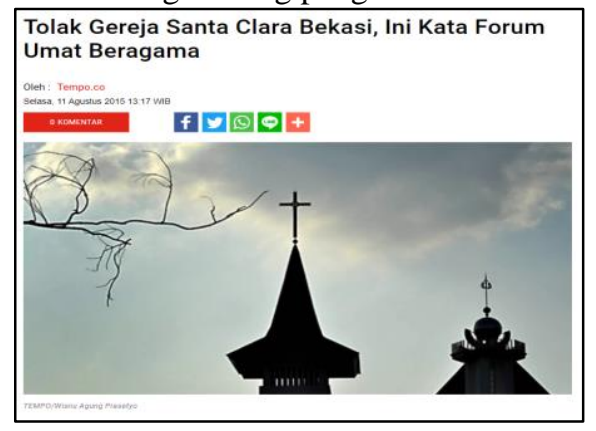

Gambar 1. Berita Penolakan Gereja di Kota Bekasi tahun 2015

Namun dalam perjalanan pemekaran dan pembangunan sarana ibadah yang baru, terdapat oknum-oknum yang menolak keberadaannya. Contohnya ada isu penolakan yang pernah terjadi di Kota Bekasi yaitu pada saat pendirian gereja Katholik Santa Clara pada tahun 2015. Pada saat itu gereja tersebut sudah memiliki izin untuk dibangun. Hal ini berdampak pada Kota Bekasi yang mendapatkan skor terendah kedua dalam Indeks Kota Toleran pada tahun 2015.

Tabel 1.

Indeks Kota Toleran Terendah Tahun 2015

\begin{tabular}{clc}
\hline No & \multicolumn{1}{c}{ Kota } & Skor \\
\hline 1 & Bogor & 5.21 \\
2 & Bekasi & 4.68 \\
3 & Banda Aceh & 4.58 \\
4 & Tangerang & 4.26 \\
5 & Depok & 4.26 \\
6 & Bandung & 4.16 \\
7 & Serang & 4.05 \\
8 & Mataram & 4.05 \\
9 & Sukabumi & 4.05 \\
10 & Tasikmalaya & 4.00 \\
\hline \hline
\end{tabular}

Namun saat ini, IKT sudah semakin membaik bahkan menempati peringkat 6 kota paling toleran versi Setara Institute pada tahun 2018. Dengan adanya berbagai yang terjadi ditengah masyarakat mengenai rumah ibadah dan lahan yang sudah banyak didominasi oleh lahan terbangun, muncul ide untuk membangun tempat pembinaan iman (gereja) sejak awal tahun 2000-an.

Eksistensi mall dengan seiring berjalannya waktu terus mengembangkan fasilitasnya. Fasilitasnya tidak hanya berupa area perbelanjaan tetapi juga seperti MICE, Hotel, dan ruang peribadatan. Mall-mall di Kota Bekasi saat ini hampir 
semuanya memiliki fasilitas tempat pembinaan iman (gereja) dari berbagai organisasi Kristen di Indonesia. Keberadaannya digerakkan oleh Aliran Kharismatik, dimana Aliran tersebut memiliki prinsip bahwa gereja maupun tempat pembinaan iman yang tidak harus menghadap ke satu arah tertentu. Pemekaran tempat pembinaan iman di mall pun terus berkembang sampai saat ini bahkan dalam 1 mall pun bisa terdiri dari beberapa fasilitas gereja dengan organisasi / pengelola yang berbedabeda.

\section{METODE PENELITIAN}

\section{A. Jenis dan Pendekatan Penelitian}

Metode yang digunakan dalam penelitian ini adalah induktifkualitatif dengan pendekatan fenomenologi, yaitu melihat fenomena berdasarkan tema-tema empiris yang ditemukan di lapangan dan mengkajinya dengan penjelasan serta makna nilai yang terkandung di dalamnya. Mengeksplor esensi yang ada dibalik eksistensi keberadaan ruang dengan konsep yang berbeda dari gereja tradisional pada umumnya dan melihat fenomena yang berangkat dari kepercayaan dan keyakinan

"Fenomelogi merupakan metode penelitian yang menekankan pada pengamatan, luas dalam bidang ilmu, terdapat esensi dibalik eksistensi, realitas dibalik kenampakan, dan noema (kesadaran intensionalitas) dibalik fenomena yang nampak." (Usop, Tari B, 2019, p.1)

"Persamaan dari kedua tipe metode penelitian Fenomenologi dan Etnografi adalah suatu penelitian yang informasi datanya pada lapangan, lokasi, mempelajari masyarakat dan belajar dari masyarakat. Akan tetapi tipe Fenomenologi berfokus pada fenomena, kepercayaan, dan keyakinan. Sedangkan tipe etnografi berfokus pada budaya yang terjadi dilingkungan masyarakarat." (Usop, Tari B, 2019, p.1)

Pada fenomena gtempat pembinaan iman di mall melihat pada tiga hal yakni manusia, nilai, ruang, dan aktivitas. Berikut adalah penjelasan rinci masing-masing:

a. Nilai yang ada pada fenomena ini adalah religi serta spiritual dan kekerabatan

b. Ruang yang ada pada fenomena ini adalah ruang pembinaan iman dan ruang komersial

c. Aktivitas pada fenomena ini adalah aktivitas religius \& spiritual, ekonomi, dan sosial budaya.

d. Manusia (actor) yang terlibat dalam penelitian ini adalah pengelola gereja, jemaat gereja, pemerintah, swasta (developer mall), dan masyarakat.

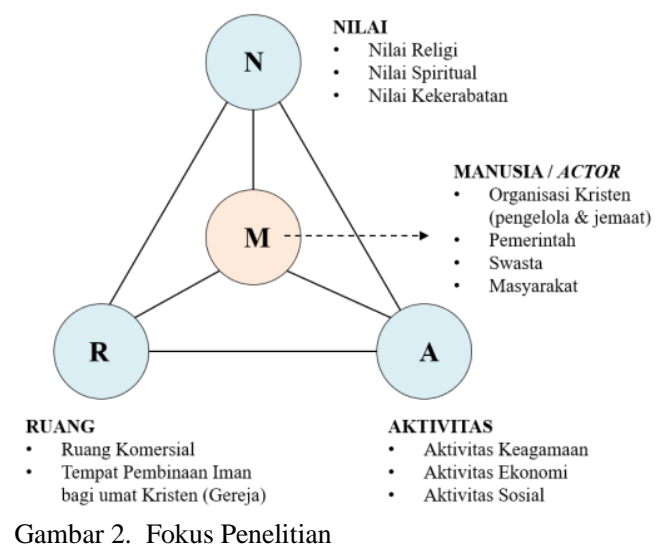

\section{B. Teknik Analisis Data}

Teknik analisis data dibagi menjadi 4 tahap, yakni mini tour, grand tour, reduksi data, penyajian data dan verifikasi data. Proses grand tour berupa wawancara, observasi lapangan, kuisioner. Proses reduksi data dengan mengumpulkan unit-unit informasi yang kemudian di kategorisasikan berdasarkan kemiripannya, dan selanjutnya digunakan tahap teorisasi.

\section{Rekrutmen Informan Penelitian}

Penulis melakukan rekrutmen terhadap informan melalui teknik purposive sampling dan snowball. Purposive sampling dilakukan untuk mendapatkan informan sesuai dengan tujuan penelitian dengan mengklasifikasikannya menjadi 4 kategori informan yaitu dari bagian pemerintah, swasta, masyarakat, dan pengelola serta jemaat. Sedangkan teknik snowball dilakukan untuk menentukan informan lain sebagai informan kunci. Pada penelitian ini, informan kunci adalah YO dan MM. Semua hasil wawancara sudah sesuai persetujuan dan diizinkan untuk dituliskan pada penelitian.

Dalam perolehan data, penulis banyak melakukan dialog dan wawancara dengan narasumber. Dari pemerintahan, penulis mewawancara 3 narasumber dari Kemenag Kota Bekasi, 2 narasumber dari Bappeda Kota Bekasi, dan 1 narasumber dari Distaru Kota Bekasi. Pengumpulan data dari pemerintahan adalah untuk mengetahui proses perizinan, pemetaan, dan menambah cakrawala tentang peraturan-peraturan rumah ibadah. Informasi gereja secara internal didapatkan dari pengurus gereja, penulis mewawancara 4 narasumber dari GTI dan GBI. Dari pihak swasta penulis mewawancara 2 narasumber yang merupakan staff mall untuk mengetahui sejarah dan status ruang. Jemaat sebanyak 33 orang sebagai narasumber untuk mengetahui sejarah, pola aktivitas, dan tanggapan mengenai eksistensi tempat pembinaan iman.

\section{HASIL DAN DISKUSI}

\section{A. Tema Empiris}

\section{1) Mall sebagai Tempat Perjumaan Umat Kristen}

Gereja dalam teologi Kristen bukan diartikan sebagai sebuah gedung rumah ibadah karena yang dimaksud gereja adalah kumpulan (persekutuan) dari para jemaat Kristiani. Dalam konteks ruang kumpul yang digunakan di mall disebut sebagai tempat pembinaan umat yang menjadi ruang untuk perkumpulan para jemaat Kristen.

"Gereja adalah suatu lembaga atau institusi yang mengantar keselamatan pada manusia" (De Jonge, Chr. Aritonang, J.S, 2009, p.5) "Gereja juga adalah persekutuan orang-orang yang ingin beribadah pada Allah" (De Jonge, Chr. Aritonang, J.S, 2009, p.5)

" [...] bukan gedungnya secara fisik tapi dari adanya persekutuan / komunitas nya. [...] Gereja saat ini banyak di mall, hotel, bahkan bioskop juga ada. Jadi dimana ada persekutuan disitulah ada gereja, bukan secara gedungnya." (YO, Wawancara 21 Februari 2020)

Berdasarkan beberapa definisi dari gereja yang didapatkan dari literatur dan wawancara, penulis mencoba melihat bahwa gereja bukan berdasarkan fisik gedung sebagai rumah ibadah namun dari perkumpulan atau persekutuan jemaat Kristen. Perkumpulan umat Kristiani di mall-mall Kota Bekasi berasal dari aliran Kharismatik.

"Gerakan Kharismatik sebenarnya bukan ajaran baru melainkan suatu koreksi terhadap kekurangan-kekurangan dengan penghayatan yang lebih intensif. Gerakan Kharismatik memiliki banyak persamaan dengan gereja Pentakosta Lama.”. (L.Sugiri, 2006, p. 290)

"Gereja Kharismatik merupakan gabungan dari sejumlah manusia dari 
berbagai ras, bangsa, dan bahasa, bahkan juga dari berbagai denominasi dan organisasi gereja. Kalangan Karismatik seringkali tidak menggunakan gedung gereja dari salah satu denominasi atau organisasi gereja yang sudah mapan dan bercorak historis tradisional.' (Sasongko, 2018, p. 5)

Beberapa diantaranya yang termasuk dalam aliran Kharismatik adalah Gereja Bethel Indonesia (GBI) dan Gereja Tiberias Indonesia (GTI). Antara GBI dan GTI mulanya merupakan satu organisasi yang sama karena GTI merupakan organisasi yang dibidani oleh GBI namun saat ini sudah memisahkan diri. Perbedaan diantara keduanya pun tidak signifikan masih ada kemiripan dalam beribadah. Umat Kristen meyakini bahwa gereja bisa berada dimana saja tanpa harus menghadap ke satu arah tertentu karena Tuhan Maha Hadir dimana saja. Saat ini, lokasi pemilihan ruang pembinaan iman oleh jemaat Kristen sering ditemui di mall, bioskop, hotel, ruko, dan gedung serbaguna yang digerakkan oleh aliran Kharismatik.

Di kota Bekasi, mall biasanya dipilih pengelola untuk memanfaatkan ruang sebagai area perjumpaan, perkumpulan, dan peribadatan para jemaat karena ketersediaan ruang yang luas dan dapat mewadahi banyaknya jemaat. Jumlah jemaat di Mall BCP dan Mega Bekasi Hypermall tiap tahun terus bertambah dan melakukan pemekaran di mall lain. Gereja Tiberias Indonesia dan Gereja Bethel Indonesia merupakan organisasi dengan jumlah jemaat yang banyak. Maka, menyewa ruang di mall dengan kapasitas banyak menjadi preferensi dari para pengelola.

\section{2) Konsep Spasial Tempat Pembinaan Iman (Gereja) di Kota} Bekasi

"[...] gereja dalam teori teologi Kristen banyak definisinya. Gereja itu adalah pribadi, organisasi, maupun dari gedung. Kenapa dibilang pribadi? Definisi gereja sendiri adalah orang yang sudah bertaubat. [...] Yang dimaksud gereja itu bukan bangunannya, tapi kumpulan orangnya." (MM, Wawancara 20 Februari 2020)

" [...] bukan esensi gedungnya secara fisik berupa bangunan gereja tapi dari adanya persekutuan / komunitas nya. [...] Gereja saat ini banyak di mall, hotel, bahkan bioskop juga ada. Jadi dimana ada persekutuan disitulah ada gereja, bukan secara gedungnya." (YO, Wawancara 21 Februari 2020)

Lokasi tempat pembinaan iman (gereja) berada di pusat kota yang menyediakan berbagai kelengkapan fasilitas lainnya. Mall pun menjadi pilihan lokasi bagi para jemaat dan pengelola karena bagi Umat Kristen beranggapan bahwa gereja bukan dimana keberadaan gedungnya namun dimana perkumpulan atau komunitas para jemaat sehingga dimanapun lokasinya para jemaat tetap bisa beribadah.

"[...] tidak ada strategi tertentu maupun marketing area dalam pemilihan lokasi, hanya saja semua berdasarkan tuntunan Tuhan, karena di dalam Kristen Awalnya pendeta kami yang menuntun kami kesini atas dorongan Tuhan, apalagi mallnya sudah semakin berkembang dan pihak mall mengizinkan (YO, Wawancara 21 Februari 2020)

Bagi pengelola tempat pembinaan iman, tidak ada strategi khusus dalam pendirian gereja baru yang belokasi di mall, hanya saja ketika ruang mall memiliki ruang yang luas dan dapat memenuhi kriteria kebutuhan kapasitas ruang, maka para pengelola memilih lokasi tersebut. Penulis melihat konsep spasial berdasarkan hasil observasi lapangan dan membagi menjadi 3 konsep, yaitu konsep makro, meso, dan mikro.

[1] Konsep makro: berada di pusat pelayanan kota, zona budidaya perdagangan dan jasa, dan merupakan kawasan strategis pusat kota yang melayani ekonomi secara kota dan regional.

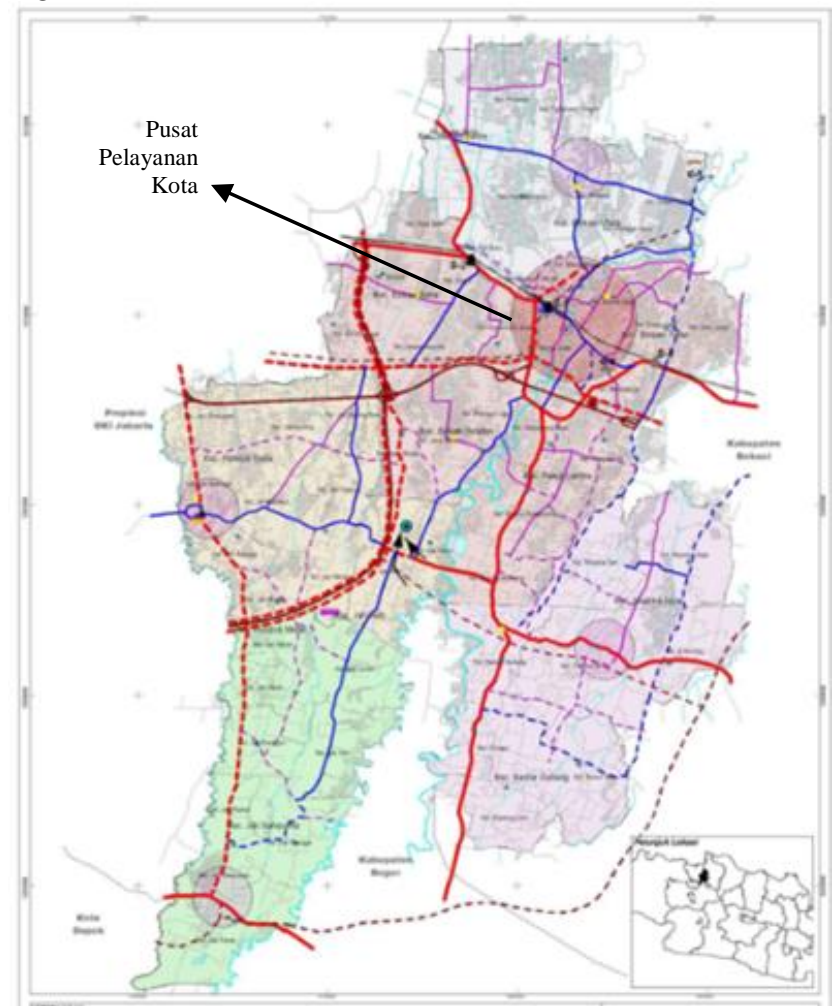

Gambar 3. Peta Rencana Struktur Ruang Kota Bekasi 2011-2031 Sumber: Distaru Kota Bekasi

[2] Konsep meso: Konsep meso dari mall yang menjadi lokasi penelitian, Bekasi Cyber Park merupakan mall dengan spesialisasi produk gadget, dilihat dari toko-toko yang dominan menjual gadget. Terdapat fasilitas lain untuk melengkapi disekitar bangunan mall, antara lain:

- Sebelah utara: Terdapat sentral niaga Kalimalang, yang dominan dengan perkantoran dan komersial

- Sebelah timur: permukiman padat penduduk

- Sebelah barat: Hotel Aston, Jl. Ahmad Yani, Islamic Centre, dan Apartemen Center Point

- Sebelah selatan: Jl. KH Noer Ali, Sungai Kalimalang, dan Mall Metropolitan

Selanjutnya, Mega Bekasi Hypermall merupakan mall dengan spesialisasi produk untuk kalangan menengah ke atas. Pada mall ini terdapat Gereja Tiberias Indonesia dan Gereja Bethel Indonesia. Selain itu, terdapat fasilitas lain di sekitar bangunan, antara lain:

- Sebelah utara: Sungai Kalimalang, Jalan Mayor Madmuin Hasibuan, Suncity Square

- Sebelah timur: permukiman padat penduduk, sungai Kalimalang

- Sebelah barat: Jalan Ahmad Yani, akses toll Bekasi Barat (Jakarta-Cikampek), Living Plaza, dan Mall Metropolitan

- Sebelah selatan: permukiman padat penduduk, Hotel Grand Amarossa, SPBU Total, SPBU Pertamina, Hotel Ibis, Apartemen Mutiara. 


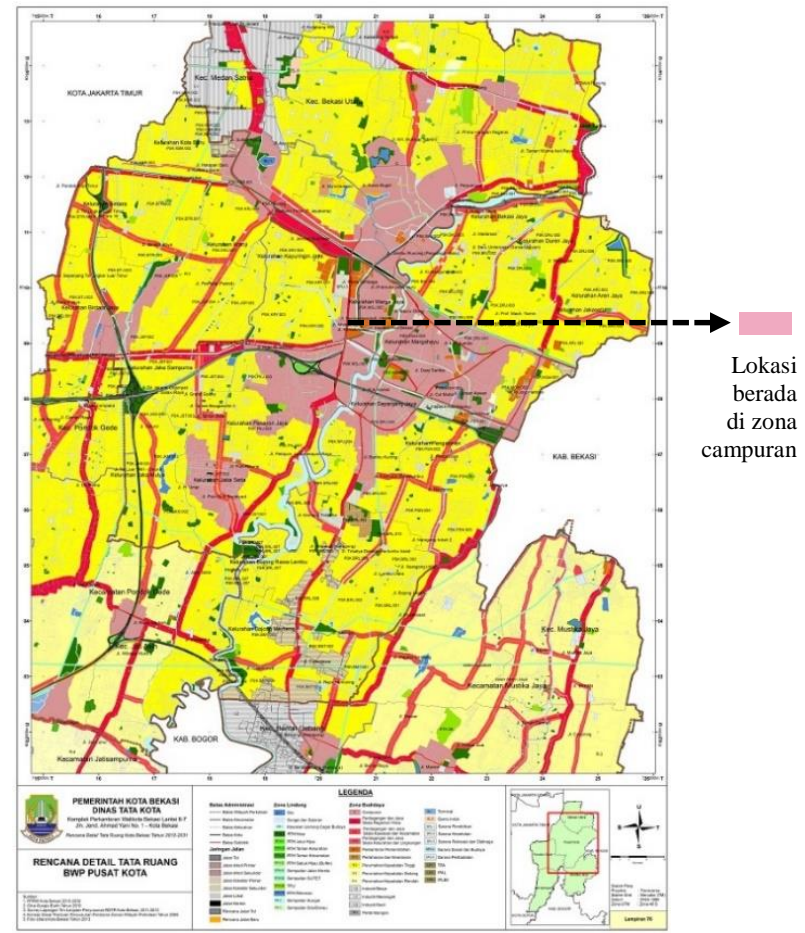

Gambar 4. Peta RDTR Kota Bekasi 2005 - 2025

Sumber: Distaru Kota Bekasi

Menurut RDTR Kota Bekasi 2005-2025 lokasi tempat pembinaan iman berada di BWP Pusat Kota. Tujuan penataan ruang BWP Pusat Kota adalah mewujudkan kawasan BWP sebagai pusat aktivitas pemerintahan, sosial, ekonomi, dan rekreasi. Perencanaan BWP Kota Bekasi yang berwawasan lingkungan, serta strategis bagi pertumbuhan ekonomi kota dan regional. Keberadaan tempat pembinaan iman (gereja) tidak menentang peraturan RDTR yang ada karena berada di zona yang tepat yakni di zona ruang campuran.

[3] Konsep mikro: berada di mixed use building yang terdiri dari mall, hotel, MICE, dan adapula mall yang sedang dikembangkan menjadi apartemen.

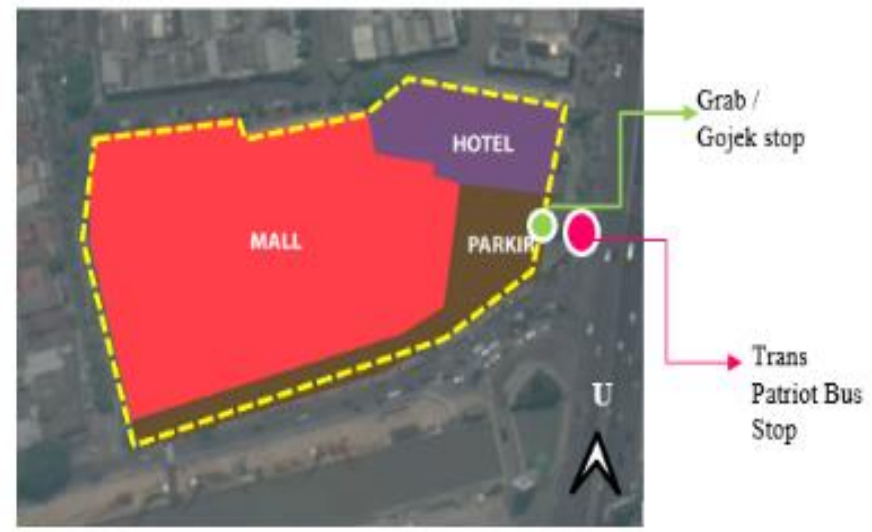

Gambar 5. Konsep Mikro Bekasi Cyber Park

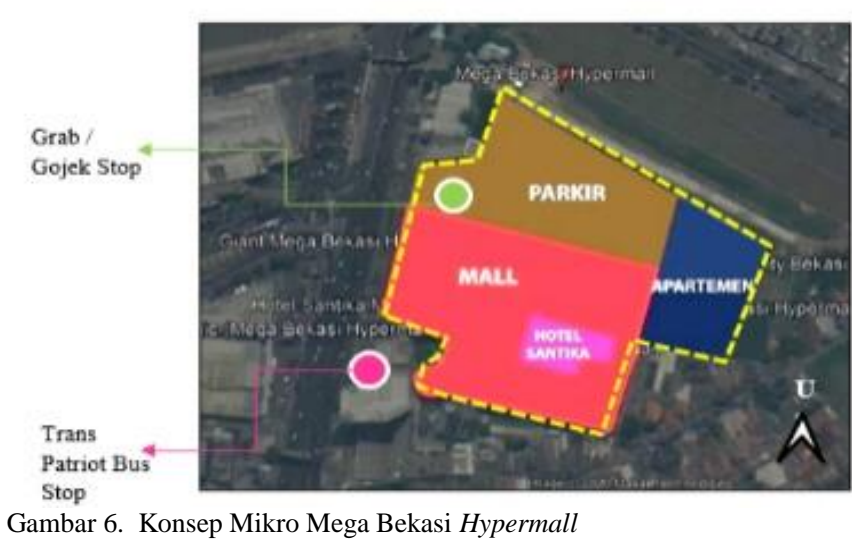

Perkembangan mall dari waktu ke waktu terlihat dari BCP mulanya adalah mall kemudian berkembang fasilitas baru seperti hotel yang dilengkapi dengan MICE (meeting, invention, conference, dan exhibition). Antara mall dan hotel bersebelahan dalam 1 area yang sama dan tempat pembinaan iman (gereja) berada di dalam mall. Sedangkan di Mega Bekasi Hypermall, mall dan hotel berada di 1 gedung yang sama dan saat ini tepat di sebelah timur (belakang mall) sedang ada penambahan fasilitas apartemen. Lokasi tempat pembinaan iman terletak didalam mall. Berada di area yang menjadi lokasi pemberhentian Trans Patriot Bekasi dan dilengkapi juga dengan pemberhentian ojek online seperti Grab maupun Gojek.

\section{3) Jaringan Lokasi}

Lokasi mall yang paling banyak diminati oleh organisasi Kristen aliran Kharismatik di Bekasi adalah Bekasi Cyber Park dan Mega Bekasi Hypermall. Meskipun pengelola menyebutkan bahwa tidak ada strategi marketing area pada pemilihan lokasi, penulis mencoba melihat karakteristik yang kuat pada lokasi penelitian.

Kedua mall ini letaknya berseberangan, berada tepat di pusat pelayanan kota (PPK) skala kota dan regional kemudian memiliki akses yang dilewati oleh Trans Patriot Bekasi. Kemudahan akses pada area ini, membuat para jemaat dapat menggunakan kendaraan umum maupun kendaraan pribadi. Jaringan lokasi mall di Kota Bekasi biasanya berlokasi berdekatan antar satu mall dengan yang lainnya. 


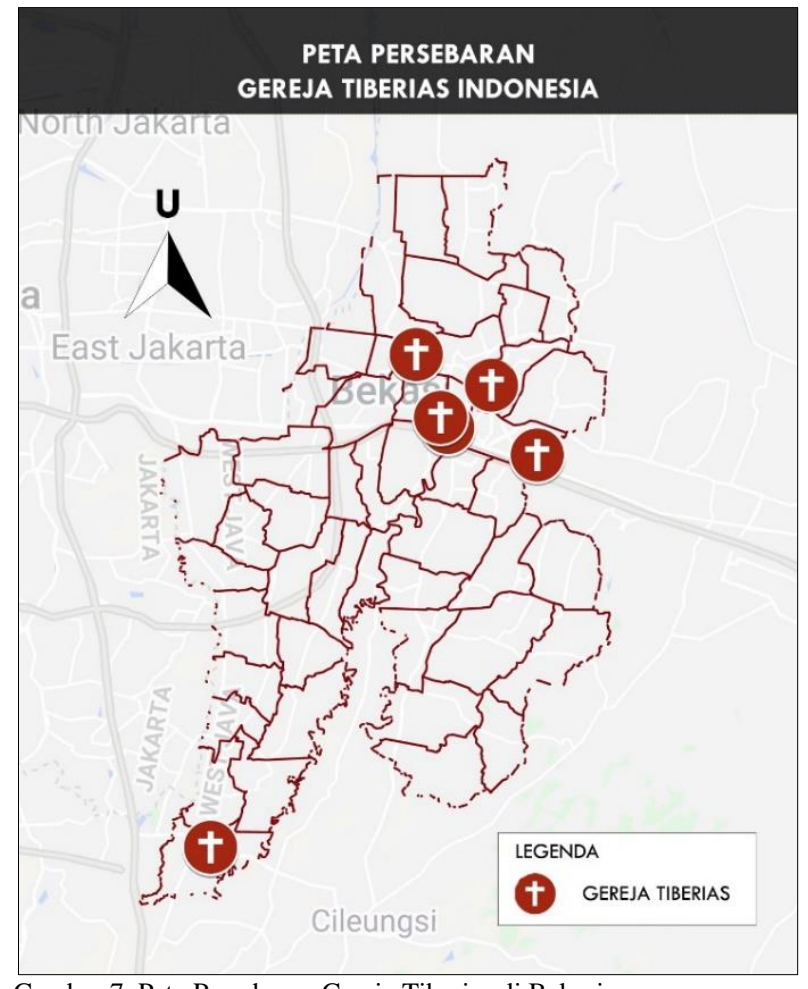

Gambar 7. Peta Persebaran Gereja Tiberias di Bekasi

Persekutuan Gereja Tiberias Indonesia tersebar di beberapa mall di Kota Bekasi, antara lain: Mega Bekasi Hypermall, Bekasi Cyber Park, Grand Mall Bekasi, Bekasi Junction. Bekasi Junction, dan Cibubur Time Square sedangkan GBI yang berlokasi di mall hanya di Bekasi Trade Center dan Mega Bekasi Hypermall.

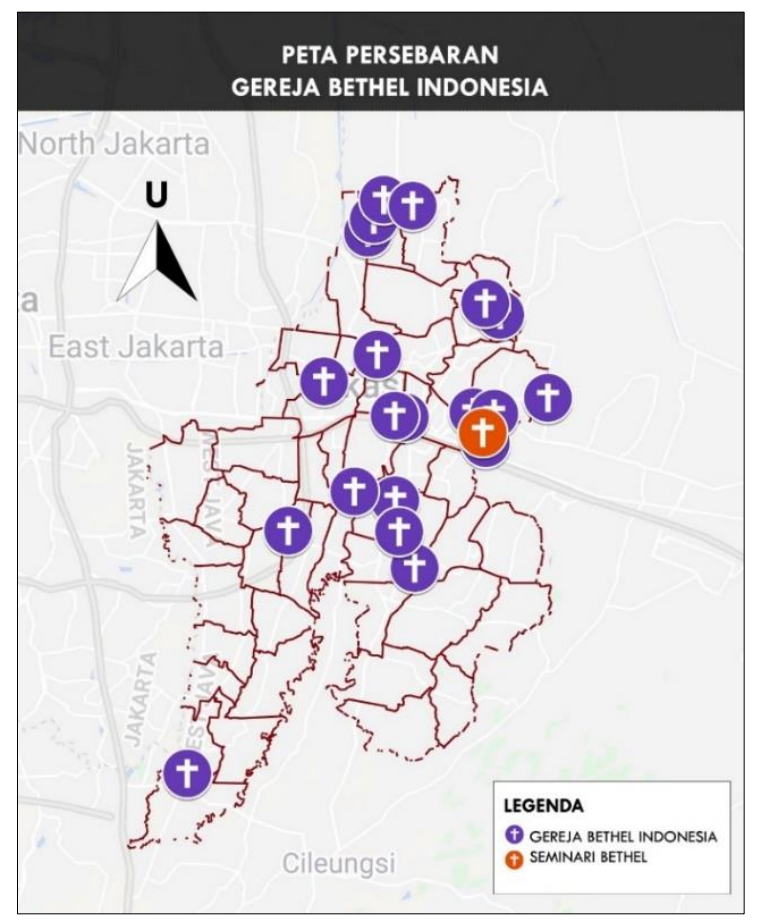

Gambar 8. Persebaran GBI di Kota Bekasi

Semua mall memiliki akses yang mudah dan dilewati oleh Trans Patriot Bekasi serta memiliki ruang-ruang yang mampu mewadahi sampai 2000 seat. Kepemilikan mall di sepanjang jalan Ahmad Yani berbeda-beda, hanya saja ada beberapa mall yang disewakan oleh organisasi Kristen yang sama untuk melakukan pemekaran karena kurangnya space dan ingin menjangkau jaringan jemaat yang lebih luas lagi.

"Mudah diakses lokasinya dan lebih merasa aman" (SC, Wawancara 16 Februari 2020)

"Minat di mall karena kenyamanan beribadah" (RUL, Wawancara 19 Januari 2020)

"Lokasi dekat dari rumah" (WW, Wawancara 19 Januari 2020)

"Pilih ibadah di mall karena supaya bisa sambil jalan-jalan" (FER, Wawancara 16 Februari 2020)

Maka, didapatkan 4 karakter jaringan lokasi pada tempat pembinaan iman di mall adalah sebagai berikut: (1) Berada di pusat pelayanan kota skala regional maupun nasional (2) Berdekatan dengan mall-mall lain yang juga memiliki fasilitas gereja (3) Memiliki akses kendaraan umum yang mudah contohnya Trans Patriot (4) Berada di zona campuran dan tipologi bangunannya adalah mixed-use.

\section{4) Karakter Ruang}

Karakter tempat pembinaan iman biasanya berada di lantai paling atas dan memiliki akses eskalator. Ditambah lagi, karakter ruang pembinaan iman biasanya berdekatan dengan restoran maupun food court atau berada dalam 1 lantai yang sama. Pada gambar 10 terlihat bahwa raung pembinaan iman yang berupa kotak berwarna merah dan foodcourt adalah kotak berwarna jingga.

Status ruangnya di mall adalah sewa dan izin yang digunakan adalah izin sementara yang berlaku selama dua tahun sehingga jika sewaktu-waktu para pengelola ingin memindahkan lokasi sangat fleksibel. Saat ini dalam 1 mall dapat terdiri dari beberapa organisasi Kristen.

"[...] izin yang digunakan adalah izin sementara, berlaku selama 2 tahun" (MM, Wawancara 7 Sepetember 2020)

"[...] ruang-ruang pembinaan iman di mall sifatnya semi permanen" (J, Wawancara 7 September 2020)

"Sewa ruang biayanya besar, tapi kelebihannya aman. Karena mall juga bertanggung jawab atas keamanan. “ (A, Wawancara 27 Februari 2020)
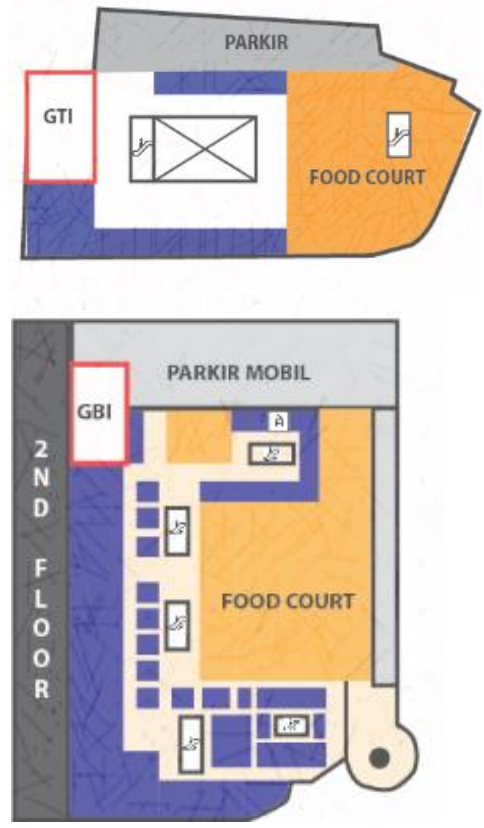

Gambar 9. Denah mall BCP \& Mega Bekasi Hypermall 
Ketersediaan ruang yang disewakan oleh mall juga menentukan keberadaan tempat pembinaan iman untuk dapat mewadahi banyaknya jemaat. Selain itu, berbeda dengan gereja yang dibangun secara permanen, interior tempat pembinaan iman (gereja) di mall ruangnya pun tidak didesain dari nol tetapi mengikuti bentuk dan ukuran ruang yang tersedia.

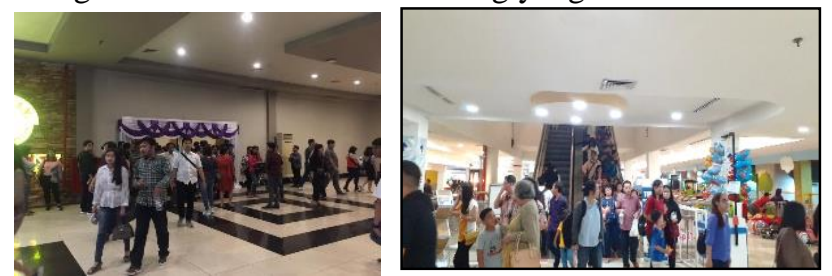

Gambar 10. Situasi Ruang Pembinaan Iman dan Foodcourt di BCP \& Mega Bekasi Hypermall

\section{5) Nilai Ruang}

Ruang mall tidak lagi dilihat sebagai ruang komersial yang merupakan memiliki nilai ekonomi namun saat ini juga memiliki nilai religi, nilai spiritual, dan nilai kekerabatan. Nilainilai tersebut muncul saat mall sudah mengembangkan fungsi ruang yang disewakan. Berikut adalah penjelasan masingmasing nilai yang terkandung dalam ruang pembinaan iman:

[1] Nilai religi: keberadaan ruang pembinaan iman yang mewadahi aktivitas para jemaat Kristen. Ruang mall yang mulanya adalah ruang-ruang profan berkembang memiliki ruang sakral dimana menjadi ruang para jemaat untuk berinteraksi dan berdoa kepada Tuhan.

"Sakral merupakan sesuatu yang superior, berkuasa, dan ketika dalam kondisi normal tidak tersentuh dan selalu dihormati. Selain itu, selalu terikat dengan peristiwa besar dalam suatu klan sedangkan yang profan adalah bagian keseharian hidup dan bersifat biasa-biasa saja dan merupakan bagian dari kehidupan pribadi." (Durkheim, 1991)

[2] Nilai spiritual: saat pengunjung mall datang tidak lagi hanya untuk sekedar berbelanja namun juga untuk meningkatkan hubungannya dengan Tuhan. Mall menjadi sarana yang mampu mewadahi kebutuhan spiritualitas umat Kristen. Dimana tempat pembinaan ini digerakkan oleh aliran Kristen yang menggunakan alunan musik yang lebih kharismatik.

"Gereja-gereja Kharismatik ini sifatnya lebih spontan dan fleksibel, tidak dilakukan dengan struktur yang kaku. Tata cara ibadah di gereja Kharismatik lebih dikenal dengan Pujian dan Penyembahan (praise and worship) yang ibadahnya memiliki ciri khas lagu pujian yang sifatnya semangat/antusiasme dan dinamis." (Sasongko, 2018, p. 5)

[3] Nilai Kekerabatan: nilai kekerabatan yang tercipta adalah antar jemaat Kristen, organisasinya, dan antar umat beragama lainnya untuk saling menghargai dan menghormati heterogenitas didalam kehidupan sosial.

\section{6) Jaringan Jemaat}

Jemaat-jemaat tidak hanya berasal dari wilayah setempat namun juga ada yang berasal dari Jakarta Timur dan hinterland Kota Bekasi. Biasanya para jemaat mengetahui keberadaan tempat pembinaan iman (gereja) berdasarkan informasi dari mulut ke mulut. Selain itu, kemudahan akses teknologi juga membuat masing-masing organisasi Kristen memiliki websitenya masing-masing sehingga memudahkan jemaat untuk mengetahui lokasi, jadwal peribadatan, dan tayangan ibadah secara live streaming.

Eksistensi tempat pembinaan iman mall sejak awal tahun 2000an dipengaruhi dengan eratnya jaringan antar persekutuan
Kristen Protestan di Indonesia. Terdapat 325 organisasi Kristen Protestan dan 7 aras (gabungan organisasi) terbesar di Indonesia yaitu PGI, PGPI, PGLII, Baptis Indonesia, Advent, Gereja Tionghoa, dan Bala Keselamatan. GBI pun masuk dalam persekutuan PGI, PGPI, dan PGLII. Sedangkan dahulu GTI berada dibawah organisasi GBI sebelum memisahkan diri namun perbedaan cara ibadah keduanya tidak signifikan. Secara lokasi pun berdekatan karena masuk dalam gabungan organisasi yang sama dan terbesar di Indonesia.

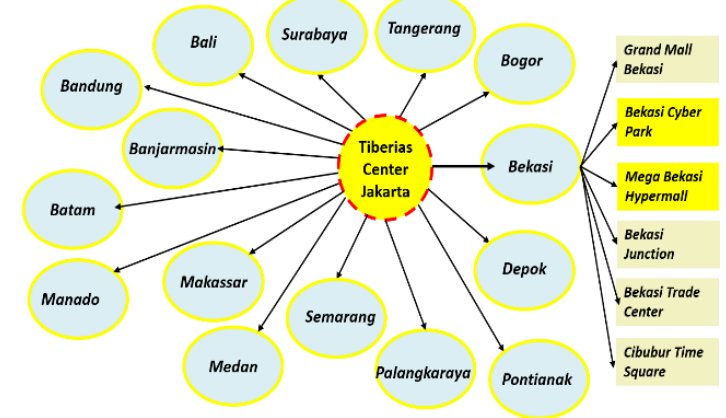

Gambar 11. Jaringan Tiberias

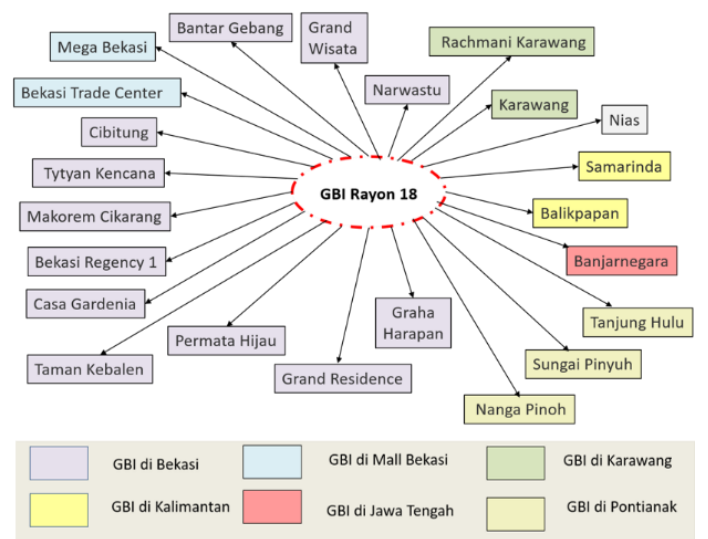

Gambar 12. Jaringan Bethel Rayon 18

Jaringan terbesar tempat pembinaan umat mall di Bekasi adalah Gereja Bethel dan Gereja Tiberias. Jemaat Tiberias dan Bethel, keduanya memiliki jemaat yang majemuk dengan pendatang dari berbagai pulau di Indonesia. Ada yang dari Sumatera, Cina, Jawa, dan lain sebagainya. Jemaat yang terdiri dari berbagai suku hadir di satu ruang, duduk bersama, dan beribadah bersama.

Selain itu, anggota dari organisasi ini biasanya adalah masyarakat yang berusia produktif dengan ekonomi menengah ke atas. Masyarakat berusia produktif memiliki minat yang tinggi untuk beribadah di mall karena akses mall yang masih dominan menggunakan eskalator dan belum ramah terhadap lansia maupun difabel. Maka, dari segi aksesibilitas dan mobilitas jemaatnya, mall lebih cocok untuk digunakan oleh masyarakat berusia produktif.

\section{7) Kerukunan dan Kekerabatan Umat Beragama}

Pada tahun 2017, sempat terjadi konflik antar umat beragama dan menolak keberadaan pendirian gereja Katholik baru di Bekasi Utara, Kota Bekasi. Penolakan tersebut berujung pada unjuk rasa di jalan oleh pihak-pihak yang tidak bertanggung jawab. Dalam penyelesaian permasalahan tersebut dilakukan oleh pemerintah untuk bersama-sama merangkul masyarakat yang ormas untuk bersama-sama membangun Kota Bekasi. 
"[...] Yang jelas dalam 2-3 tahun terakhir Pemkot Bekasi / Wali Kota benar-benar merangkul dan memberdayakan ormas / LSM. Contoh yang belum lama ini heboh terkait ormas yang diberi kewenangan untuk menarik tarif parkir di ruko-ruko/alfamart, dll. Bahkan sangat sering ormas/ LSM diajak bersama mendengarkan arahan Wali Kota. Mungkin dengan pendekatan tersebut ormas / LSM bisa diredam dan diajak bersama untuk menciptakan toleransi di Kota Bekasi" (BMB, Wawancara 14 Februari 2020)

Bentuk rangkulan yang ditawarkan oleh pemerintah Kota Bekasi adalah bersama-sama dengan ormas menarik tarif parkir di beberapa titik minimarket. Salah satu contoh bentuk pendekatan seperti itulah yang diterapkan oleh Pemkot Bekasi mengingat Kota Bekasi pernah menduduki Indeks Kota Toleran terendah ke-2 pada tahun 2015 menurut Setara Institute. Dengan rangkulan pemerintah, saat ini indeksnya sudah membaik dan menduduki peringkat ke- 6 kota paling toleran di Indonesia.

Tabel 2.

Indeks Kota Toleran 2018

\begin{tabular}{cll}
\multicolumn{3}{c}{ Indeks Kota Toleran 2018 } \\
\hline \hline \multirow{2}{*}{ No } & \multicolumn{1}{c}{ Kota } & Skor \\
& & \\
\hline 1 & Singkawang & 6.513 \\
2 & Salatiga & 6.477 \\
3 & Pematang Siantar & 6.280 \\
4 & Manado & 6.030 \\
5 & Ambon & 5.960 \\
6 & Bekasi & 5.890 \\
7 & Kupang & 5.857 \\
8 & Tomohon & 5.833 \\
9 & Binjai & 5.830 \\
10 & Surabaya & 5.823 \\
\hline \hline
\end{tabular}

Selain itu, pemerintah juga mengedukasi masyarakatnya untuk hidup secara berdampingan dan didukung juga oleh Forum Kerukunan Umat Beragama (FKUB). Pemerintah, pengelola gereja, dan FKUB mengedukasi dan mensosialisasikan bahwa gereja maupun tempat pembinaan iman bukan gedung / fisiknya namun dilihat sebagai perkumpulan dari para jemaatnya. Dengan memberikan pengertian tersebut, akhirnya masyarakat lebih bisa menerima keberadaan tempat pembinaan iman di mall.

\section{8) Peran Pihak-Pihak terkait}

Yang berperan dalam eksistensi tempat pembinaan iman di mall adalah 4 pihak. Yang pertama adalah [1] pengelola organisasi Kristen, [2] pemerintah, [3] swasta, [4] masyarakat. Dalam dapat beroperasionalnya fasilitas keagamaan tersebut, organisasi Kristen di mall menggunakan izin sementara.

"Izin sementara adalah izin yang dikeluarkan oleh Walikota bagi penggunaan bangunan yang bukan diperuntukkan untuk kegiatan peribadatan.” Peraturan Wali Kota Bekasi No 16 tahun 2006.

Dalam pemberian izin sementara dengan syarat-syarat administrasi yang sudah ditentukan dalam rangka menjaga ketertiban dan ketentraman di tengah masyarakat. Berikut adalah peran dari masing-masing pihak: [1] pengelola organisasi Kristen: mengajukan izin secara tertulis mengenai pemanfaatan ruang sebagai tempat pembinaan iman kepada pemilik ruang dan melakukan pelaporan tertulis kepada FKUB, Kemenag, dan Dinas Solinbermas. [2] pemerintah: lurah memberikan rekomendasi pemanfaatan ruang diketahui oleh camat dan ketika semua persyaratan administrasi sudah terverifkasi, Walikota memberikan izin sementara secara tertulis kepada pihak pengelola organisasi Kristen [3] swasta: developer mall sebagai pemilik ruang dan mengizinkan ruangnya dimanfaatkan untuk kegiatan peribadatan, menjamin keamanan penggunaan ruang, maintenance gedung menjadi wewenang dari developer mall. [4] masyarakat: memberikan pernyataan tidak keberatan dari lingkungan setempat paling sedikit 60 orang diketahui oleh RT dan RW, kemudian keberadaan FKUB juga sangat membantu untuk menampung aspirasi masyarakat dan ormas, melakukan dialog dengan pemuka agama, dan memberikan rekomendasi tertulis dengan permohonan keberadaan tempat pembinaan iman yang baru.

\section{9) Mobilitas Jemaat}

Dari hasil wawancara dan kuisioner, mayoritas jemaat setelah sampai di mall langsung ke ruang ibadah untuk beribadah. Meskipun berlokasi di mall, namun tujuan utama para jemaat adalah untuk beribadah. Namun ketika datang lebih awal dan ada waktu tersisa cukup panjang, ada jemaat yang hangout di mall seperti ke toko buku dan tenant lain. Selain itu, setelah beribadah jemaat mayoritas melakukan makan bersama di mall. Hal ini dikarenakan ruang ibadahyang tidak jauh dari foodcourt atau tenant-tenant makanan lainnya.

[...] Tidak ada, langsung ke tujuan utama ke gereja (R, Wawancara November 2019)

[...] Kelebihan gereja di mall bisa sebelum atau sesudah ibadah sekalian makan atau belanja." (HER, Wawancara Februari 2020)

[...] Milih gereja di mall biar bisa fleksibel jadi bisa langsung main setelah gereja" (NDY, Wawancara Februari 2020)

Para jemaat yang beribadah di mall, tidak menghilangkan makna ruang meskipun berada di kawasan yang padat dari segi mobilitasnya. Adapun keberadaan ruang pembinaan iman di mall juga menguatkan perjumpaan antar jemaat karena setelah beribadah bersama, para jemaat melakukan makan bersama di restoran atau foodcourt. Konsep beribadah sambil refreshing pun menjadi diminati oleh umat Kristiani mengingat terus berkembangnya organisasi Kristen lainnya yang memilih mall sebagai area pemekaran yang baru. Berikut adalah karakter mobilitas jemaat sebelum dan sesudah beribadah berdasarkan hasil wawancara dan pengamatan lapangan:

Terdapat tiga tipe jemaat berdasarkan pola aktivitas sebelum dan setelah beribadah, antara lain:

[1] Ketika sampai di mall, langsung ke ruang ibadah dan sesudah beribadah hangout di mall

[2] Ketika sampai di mall, langsung beribadah dan sesudah beribadah langsung pulang

[3] Ketika sampai di mall, hangout dahulu dan setelah beribadah langsung pulang.

Selain itu, perkembangan fasilitas mall tidak diimbangi dengan fasilitas parkirnya. Hal ini membuat para jemaat terkadang kesulitan mencari area parkir kendaraan pribadi dan tidak sedikit yang memilih untuk menggunakan transportasi ojek online. Keberadaan parkir-parkir liar di sekitar mall menjadi diminati oleh para jemaat karena lebih mudah parkir dalam kondisi tertentu dan menawarkan tarif yang lebih murah daripada di gedung parkir.

"[...] Disini parkirnya susah. Sampai pengelola mall nambah fasilitas parkir di lantai P3, ditambah valet parking khusus untuk anggota gereja dengan selisih tarif yang lumayan tinggi (YO, Wawancara 21 Februari 2020)

Dari hasil wawancara dan kuisioner, mayoritas jemaat menggunakan kendaraan pribadi karena lokasi rumah yang tidak terlalu jauh dari lokasi mall sedangkan yang masih single dan rumahnya lumayan jauh, jemaat memilih untuk menggunakan ojek online dan koasi. Peminat Trans Patriot 
masih kurang meskipun tepat di depan mall terdapat halte pemberhentian bus Trans Patriot. Dari sisi memilih parkir pun berbeda-beda. Bagi para pengendara mobil pasti menggunakan parkir mall sedangkan pengendara motor ada yang memilih parkir di luar karena lebih murah. Maka, pemilihan akses dan parkir dibagi menjadi tiga, antara lain:

[1] Terdapat jemaat menggunakan kendaraan pribadi (motor) dan parkir di luar mall (yang dikelola masyarakat)

[2] Terdapat jemaat yang menggunakan kendaraan pribadi (motor \& mobil) dan parkir di dalam mall

[3] Terdapat jemaat yang menggunakan kendaraan umum (koasi dan ojek online) dan tidak parkir

\section{B. Kategorisasi Tema}

Kategorisasi atau di sebut juga perumusan tema dalam analisis indusktif dengan mengelompokkan tema-tema temuan empiris atau komentar eksploratis yang sejenis dari para partisipan untuk kemudian dikembangkan dalam bentuk abstraksi interpretasi.

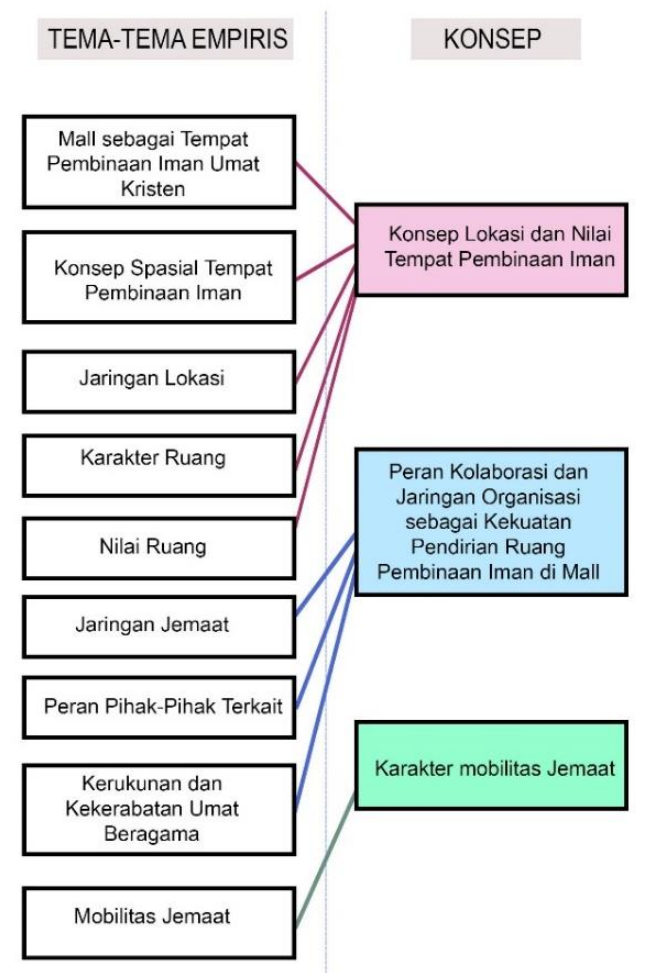

Gambar 13. Kategorisasi Tema

Terdapat 9 unit-unit informasi yang sudah terkumpul kemudian dikategorisasikan menjadi 3 konsep tema, yaitu: konsep lokasi dan nilai ruang, peran kolaborasi dan jaringan karakter mobilitas.

\section{1) Jaringan Lokasi dan Nilai Ruang Tempat Pembinaan Iman}

Konsep lokasi tempat pembinaan iman di mall adalah sebagai berikut:

- Berada di pusat pelayanan kota skala regional maupun nasional

- Berdekatan dengan mall-mall lain yang juga memiliki fasilitas gereja

- Memiliki akses transportasi umum yang mudah contohnya Trans Patriot
- Berada di zona campuran dan tipologi bangunannya adalah mixed-use

- Biasanya berada di lantai paling atas dan dekat dengan tenant makanan atau foodcourt

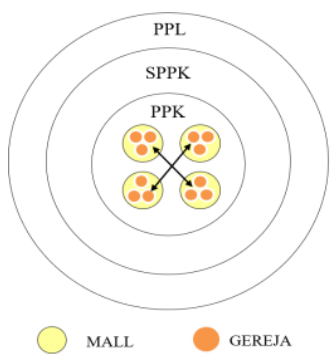

Gambar 14. Jaringan Lokasi

Nilai ruang pada tempat pembinaan iman dibagi menjadi 2 ruang yakni yang sakral dan yang profan. Ruang yang sakral memiliki nilai religi, spiritual, dan kekerabatan sedangkan ruang yang profan memiliki nilai ekonomi, inklusi, dan identitas seperti pada nilai ruang kota. Berikut adalah penjelasannya:

- Nilai religi: keberadaan ruang pembinaan iman yang mewadahi aktivitas para jemaat Kristen. Ruang mall yang mulanya adalah ruang-ruang profan berkembang memiliki ruang sakral dimana menjadi ruang para jemaat untuk berinteraksi dan berdoa kepada Tuhan.

- Nilai spiritual: saat pengunjung mall datang tidak lagi hanya untuk sekedar berbelanja namun juga untuk meningkatkan hubungannya dengan Tuhan. Mall menjadi sarana yang mampu mewadahi kebutuhan spiritualitas umat Kristen. Dimana tempat pembinaan ini digerakkan oleh aliran Kristen yang menggunakan alunan musik yang lebih kharismatik.

- Nilai Sosial dan Kekerabatan: nilai kekerabatan yang tercipta adalah antar jemaat Kristen, organisasinya, dan antar umat beragama lainnya untuk saling menghargai dan menghormati heterogenitas didalam kehidupan sosial.

- Nilai ekonomi: nilai uang sewa yang dibayarkan oleh pengurus gereja membuat mall-mall mengalami kenaikan jumlah pengunjung dan pertumbuhan secara ekonomi.

- Nilai inklusi: dimana tempat pembinaan iman (gereja) di mall menjadi sangat terbuka bagi siapapun umat Kristen yang ingin beribadah di mall.

- Nilai identitas: dimana tempat pembinaan iman (gereja) di mall memiki identitas menjadi tempat berkumpulnya jemaat-jemaat Kristen karena didalam 1 mall dapat ditemui hingga 3 organisasi Kristen yang berbeda.

2) Peran Kolaborasi dan Jaringan Organisasi sebagai Kekukatan Pendirian Ruang Pembinaan Iman di Mall

Jaringan organisasi tempat pembinaan iman (gereja) di mall berkumpul di pusat kota, organisasi-organisasi tersebut terbentuk dalam aras persekutuan Kristen di Indonesia. Yang beribadah di mall tidak hanya penduduk yang bermukim di sekitar mall namun juga ada yang dari hinterland pusat kota. Jaringan organisasi Kristen terbesar di mall Bekasi adalah Gereja Bethel dan Gereja Tiberias. Keduanya merupakan organisasi Kristen yang juga sudah eksis di beberapa wilayah di Indonesia. Meskipun tidak semua lokasi gereja berada di 
mall namun pemilihan lokasi di mall karena lebih fleksibel dan dapat mewadahi banyaknya jemaat. Keberadaan banyaknya organisasi Kristen di 1 mall yang sama membuat ruang-ruang mall disewakan oleh persekutuan Kristen lainnya.

Tabel 3.

Organisasi Kristen dan Lokasi di Mall (area Bekasi Selatan)

\begin{tabular}{cll}
\hline \hline No & \multicolumn{1}{c}{ Nama Organisasi } & \multicolumn{1}{c}{ Lokasi } \\
\hline 1 & Gereja Bethel Indonesia & Mega Bekasi Hypermall \\
2 & Gereja Tiberias Indonesia & BCP \& Mega Bekasi Hypermall \\
3 & BICC & Mega Bekasi Hypermall \\
4 & Gereja Bethany & BCP \\
\hline \hline
\end{tabular}

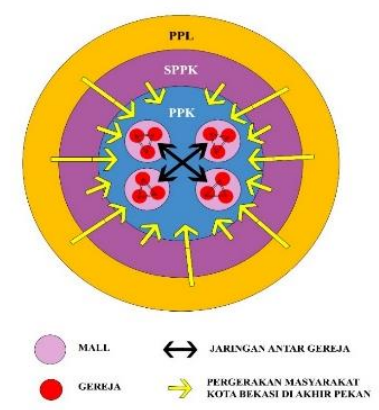

Gambar 15. Jaringan Jemaat

Pendirian rumah ibadah baru seperti gereja tidak hanya dilakukan oleh satu pihak. Banyak pihak yang ikut turut serta dalam pendirian dan perizinan rumah ibadah baru, yaitu:

- Swasta selaku pemilik ruang yang mengizinkan untuk digunakan sebagai gereja

- Pemerintah dan dinas terkait yang menyetujui kehadiran tempat pembinaan iman dengan mengeluarkan izin sementara

- Masyarakat selaku partisipan menyetujui adanya kehadiran gereja baru

- Pengelola gereja yang mengumpulkan jemaat yang membutuhkan ruang ibadah baru.

Secara hirarki dalam kolaborasi pendirian rumah ibadah baru tidak bisa dilihat hanya dari satu sisi. Jika dari segi persiapan, yang paling berpengaruh adalah pengelola dan calon jemaat. Dari segi pengadaan ruang, swasta yang paling berpengaruh karena izin untuk didirikannya ibadah diiperbolehkan / tidak. Dari segi perizinan, kuasa tertinggi adalah pemerintah. Pemerintah dari tingkat kelurahan sampai tingkat walikota ikut serta dalam verifikasi pendirian gereja baru. Dari segi operasional, pengelola dan jemaat memiliki kuasa penuh untuk mendapatkan hak keamanan serta perawatan gedung.

\section{3) Karakter Mobilitas Jemaat}

Jika dilihat fitur google traffic yang dapat mengindikasi tinggirendahnya kemacetan di suatu lokasi. Dari gambar dapat dilihat bahwa kepadatan tertinggi berada di pusat pelayanan kota dan zona perdagangan \& jasa. Area pusat pelayanan kota tersebut adalah lokasi tempat pembinaan iman (gereja) di mall berada.

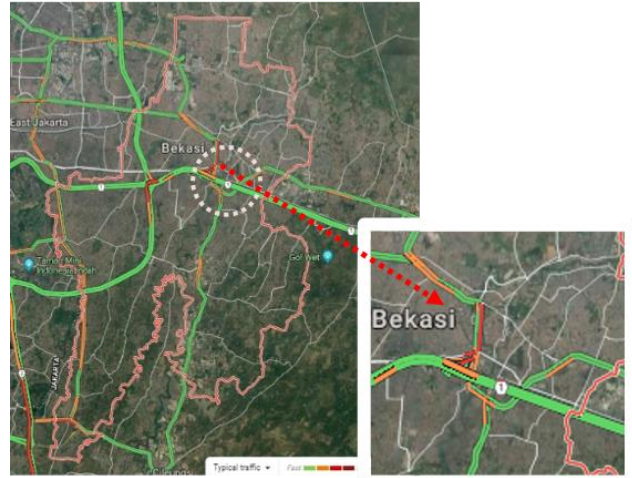

Gambar 16. Pergerakan Masyarakat Kota Bekasi Sumber: Google Traffic, 2020

Pergerakan masyarakat Kota Bekasi yang paling diminati dan sering terjadi kemacetan adalah di Jalan Ahmad Yani. Dalam satu koridor jalan terdapat 4 mall, yaitu Bekasi Cyber Park, Mega Bekasi Hypermall, Mall Metropolitan, dan Living World. Keberadaan mall-mall tersebut memicu masyarakat untuk menuju ke lokasi saat akhir pekan bahkan pada hari biasapun karena Jalan Ahmad Yani juga akses utama menuju jalan toll ke dalam dan luar kota, maka pada jalan tersebut sering terjadi kemacetan.

Para jemaat biasanya memiliki ekonomi menengah ke atas. Kebanyakan dari mereka menggunakan kendaraan pribadi seperti motor dan mobil sedangkan kendaraan umum yang digunakan adalah ojek online. Berikut adalah pola berkendara para jemaat:

- Menggunakan kendaraan pribadi (motor maupun mobil), ketika sampai di mall memilih untuk parkir di gedung mall

- Menggunakan kendaraan pribadi (motor), tidak memilih parkir di gedung mall dan memilih parkir di luar mall (parkir liar) karena tarifnya yang lebih murah

- Menggunakan kendaraan umum seperi ojek online dan berhenti di depan Grab / Gojek spot tepat di depan mall.

Pola mobilitas sebelum dan sesudah beribadah terdapat tiga tipe jemaat berdasarkan pola aktivitas sebelum dan setelah bergereja, antara lain:

- Ketika sampai di mall, langsung ke gereja dan sesudah beribadah hangout di mall.

- Ketika sampai di mall, langsung beribadah dan sesudah beribadah langsung pulang

- Ketika sampai di mall, hangout dahulu dan setelah beribadah langsung pulang

\section{Teorisasi}

Teorisasi adalah proses akhir dalam perjalanan penelitian induktif kualitatif. Pada bagian ini akan menunjukkan hasil akhir dari proses induksi dari tema-tema empirik, yaitu tematema kecil yang di bentuk berdasarkan unit informasi dari beberapa informan tentang fakta di lapangan terkait sejauh mana pertumbuhannya serta kaitannya dengan jaringan gereja dan lokasi tempat pembinaan iman di mall Kota Bekasi.

Pergerakan masyarakat yang cenderung menuju pusat kota untuk melakukan kegiatan menuju perkantoran, pemerintahan, perdagangan dan jasa, pendidikan, peribadatan dan lain sebagainya. Keberadaan tempat pembinaan iman (gereja) di mall di Bekasi sejak awal tahun 2000an sangat memudahkan 
para jemaat untuk beribadah karena selain lokasinya yang strategis namun juga lengkapnya ketersediaan fasilitas yang disediakan.

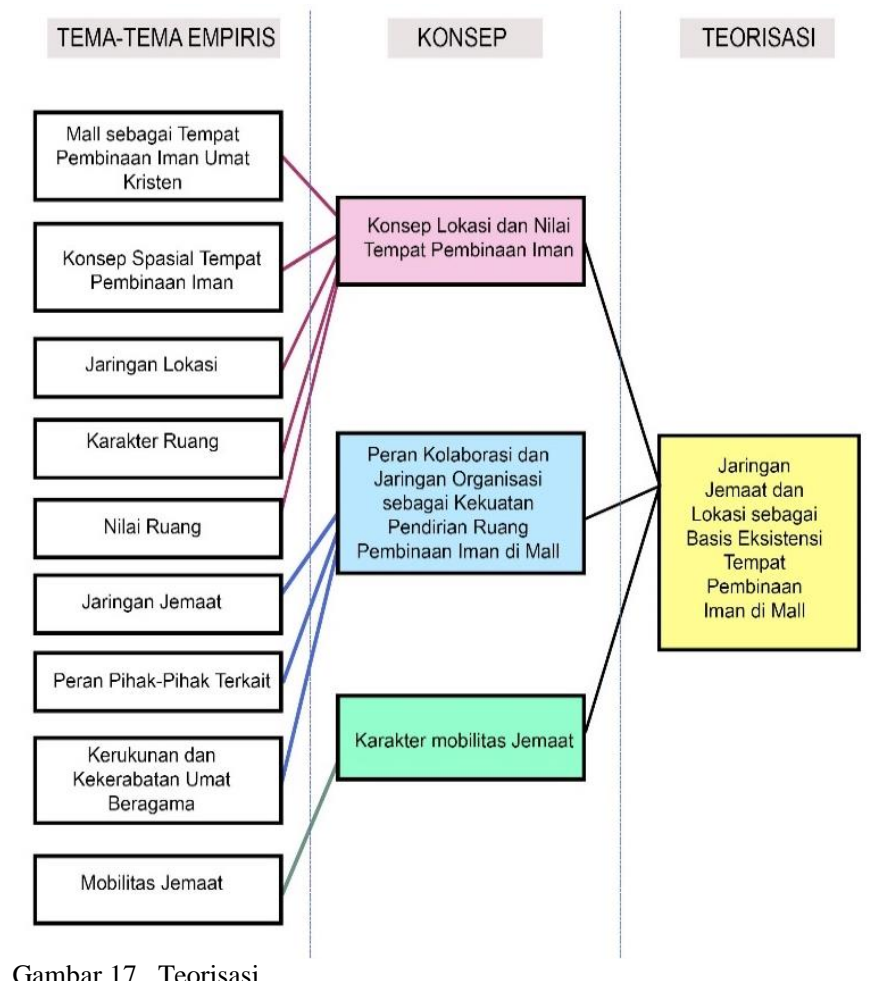

Eksistensi tempat pembinaan iman (gereja) di mall yang masih berlangsung sampai saat ini didukung dengan adanya aliran Kharismatik. Bagi aliran tersebut sama seperti ajaran yang diyakini oleh umat Kristen lainnya bahwa gereja dapat berada dimana saja. Kebebasan memilih tempat beribadah dimanapun dan bebas menghadap arah manapun memunculkan ide dari para pengelola gereja untuk membuat tempat pembinaan iman (gereja) di mall. Kedekatan mall satu dengan yang lainnya juga mendukung dan membuat eksistensi gereja semakin berkembang karena masih memungkinkan untuk terus bertambah oleh organisasi Kristen maupun aliran Kharismatik lainnya.

\section{KESIMPULAN}

Dalam perjalanan eksistensi tempat pembinaan umat (gereja) di mall sejak awal tahun 2000-an mengalami berbagai proses yang harus dihadapi oleh para pengelola gereja. Sempat adanya penolakan dan isu-isu dari oknum tidak bertanggung jawab yang akhirnya mampu diatasi oleh pemerintah setempat. Sosialisasi bahwa gereja maupun tempat pembinaan iman bukan dilihat dari esensi gedungnya namun dari perkumpulan membuat masyarakat teredukasi dengan baik dan meredam segala konflik yang memicu perdebatan diantara umat beragama lainnya

Eksistensi tempat pembinaan iman (gereja) ditandai dengan area perkumpulan atau perjumpaan jemaat yang digunakan untuk pembinaan iman. Keberadaanya berasal dari aliran
Kharismatik. Yang termasuk dalam aliran ini beberapa diantaranya adalah Gereja Tiberias Indonesia dan Gereja Bethel Indonesia. Aliran ini memiliki paham yang sama dengan umat Kristen pada umumnya yang melihat gereja tidak hanya gedungnya tetapi dari perkumpulan jemaat yang ingin beribadah maupun bertaubat. Ditambah lagi, gereja maupun tempat pembinaan iman boleh menghadap ke arah manapun tanpa harus menghadap satu arah tertentu sehingga keberadaannya di mall juga tidak menentang ajaran yang diyakini, dan sesuai dengan rencana tata ruang kota yang berada di zona campuran.

Masing-masing organisasi Kristen memiliki area perjumpaan sesuai dengan preferensinya masing-masing. Konsep beribadah sambil refreshing di mall menjadi sangat diminati oleh jemaat. Hal ini juga didukung oleh semakin berkembangnya organisasiorganisasi aliran Kharismatik lain yang terpicu untuk melakukan pemekaran di lokasi mall yang sama dan peran pihak-pihak terkait secara kolaboratif dalam mendukung eksistensinya di mall sangat berpengaruh. Sampai saat ini, tempat pembinaan iman (gereja) di mall terus memperlihatkan eksistensinya dan terus adanya penambahan layanan publik yang disediakan oleh pengelola mall meskipun dari segi area parkir sudah sedikit sulit karena semakin bertambahnya fasilitas dalam 1 area yang sama. Namun hal ini tidak menurunkan semangat dari para jemaat untuk melakukaan pembinaan iman di mall.

\section{DAFTAR PUSTAKA}

[1] Fajrin, A. (2017). FASILITAS SOSIAL GEREJA INFORMAL DI KOTA YOGYAKARTA ARDHI MAULANA FAJRIN, Ir. Agam Marsoyo, M.Sc., Ph.D. (Issue 1). Universitas Gadjah Mada.

[2] Farjam, R., \& Hossieni Motlaq, S. M. (2019). Does urban mixed use development approach explain spatial analysis of inner city decay? Journal of Urban Management, 8(2), 245-260. https://doi.org/10.1016/j.jum.2019.01.003

[3] Halili. (2018). Indeks Kota Toleran (IKT) Tahun 2018. ResearchGate, November.

[4] International Downtown Association. (2018). The Value of $U . S$. Downtowns and Center Cities.

[5] Nugroho, S. (2017). Gereja Likuid di Tengah Masyarakat Pascamodern. Universitas Sanata Dharma.

[6] Rodemeier, S. (2016). Kajian Atas Gereja Pentakosta-Kharismatik di Jawa, Indonesia: Sebuah Tantangan. Gema Teologika, 1(1), 31. https://doi.org/10.21460/gema.2016.11.210

[7] Sasongko, H. (2019). Gereja Karismatik dan Inkulturasi Musik di Dalam Sistem Ibadahnya. Selonding, 13(13), 1913-1927. https://doi.org/10.24821/selonding.v13i13.2916

[8] Usop, T. B. (2016). Kajian Literatur Metodologi Penelitian Fenomenologi dan Etnografi. Researchgate, 1(1), 1-12. https://doi.org/10.13140/RG.2.2.15786.47044

[9] Van Manen, M. (2017). But Is It Phenomenology? Qualitative Health Research, 27(6), 775-779. https://doi.org/10.1177/1049732317699570

[10] Wahjusaputri, S., \& Fitriani, S. (2016). Religious Harmony in Indonesia (Learning Harmony and Religious Tolerance of Kampung Sawah Society In Bekasi City). Prosiding Kolokium Doktor Dan Seminar Hasil Penelitian Hibah Tahun 2016, 115-121. http://repository.uhamka.ac.id/566/1/SINTHA-4.pdf

[11] Widiyani. (2018). Shopping behavior in malls. Eindhoven University of Technology. 